Kwartalnik Historyczny

Vol. CXXVII, 2020

Eng.-Language Edition no. 4, pp. 47-76

PL ISSN 0023-5903

\title{
DOROTA DUKWICZ
}

https://orcid.org/0000-0002-1135-589X

The Tadeusz Manteuffel Institute of History

of the Polish Academy of Sciences, Warsaw

\section{PUBLICATION OF PRUSSIAN DIPLOMATIC MATERIALS IN THE SBORNIK IMPERATORSKOGO RUSSKOGO ISTORICHESKOGO OBSHCHESTVA AS A TOOL OF THE POLITICS OF HISTORY OF THE RUSSIAN EMPIRE: REMARKS ON THE COMPLETENESS OF THE EDITION*}

Abstract: At the turn of the nineteenth century many European states began to publish multi-volume editions of sources illustrating the political history of these states in previous centuries (for example, the Prussian Politische Correspondenz Friedrich's des Großen). The Russian Sbornik Imperatorskogo Russkogo Istoricheskogo Obshchestva published by the Imperial Russian Historical Society is still used by researchers. It seems worthwhile to focus on the Sbornik and to assess its value as a scholarly edition using the Prussian diplomatic correspondence, included in that edition as a test-case.

Ke y w o r d s: SIRIO, Sbornik RIO, Imperial Russian Historical Society, source edition, historical policy/politics.

The Imperial Russian Historical Society (Imperatorskoe Russkoe Istoricheske Obshchestvo, hereafter RIO) was established in 1866 and survived until $1920 .{ }^{1}$ From the very beginning it was an elite association connecting the most important persons in the state (including the rulers themselves or the heirs to the throne, of which, for example, Tsar Nicholas II was the honorary chairman of the Society) with the group of the prominent researchers. ${ }^{2}$ One can mention the names of Sergei M. Solov'ev,

\footnotetext{
${ }^{*}$ The article was written in the framework of the research project of the National Science Centre in Poland (NCN Opus 2018/29/B/HS3/01149).

${ }^{1}$ The most complete outline of the RIO's history was presented in the article 'Istoriia Rossiiskogo istoricheskogo obshchestva' 〈https://historyrussia.org/ob -obshchestve/istoriya.html $>$ [accessed 29 March 2019], published on the webpage of the Society, which was reactivated in 1991.

${ }^{2}$ Vera Kaplan, Historian and Historical Societies in the Public Life of Imperial Russia, Bloomington, IN, 2017, pp. 105-06.
} 
Vasilii O. Kliuchevskii, Aleksandr S. Lappo-Danilevskii, Fedor F. Martens or Nikolai D. Chechulin. The RIO was informally linked to the Russian Ministry of Foreign Affairs, ${ }^{3}$ but formally worked under auspices of the Ministry of Public Education. The Statute of the RIO was personally approved by Tsar Alexander II. From 1873 the Society was officially under state patronage and had the word 'Imperial' (Imperatorskoe) added in its name. From 1876 until the February Revolution in 1917 it was fully financed from the state funds. Before that, through its first decade a substantial part of the RIO's funding was from private donations of members of the ruling family. As a result, the Society realized Russia's politics of history, that is, created the Russian imperial enforced vision of history. A recent Russian researcher expressed it thus: 'When preparing material for publication the most important thing was the principle of protection of the state interests'. ${ }^{4}$

In the world of historians dealing with modern Russia, the RIO is mainly known due to the two great editorial projects. The first one, which is the focus of this article, was the Sbornik Imperatorskogo Russkogo Istoricheskogo Obshchestva (hereafter SIRIO or the Sbornik), published in 148 volumes between 1867 and 1918 (so from the beginning to the end of the RIO's existence). It was the main undertaking of the Society, which was in fact founded to edit the Sbornik. The other project was the Russian biographical dictionary (Russkii Biograficheskii Slovar') $)^{5}$ in twenty-five volumes. The idea of publishing the dictionary emerged in 1875 , along with the work on SIRIO. Both publications used to be systematically, sent free of charge not only to academic institutions in the empire, but also to the leading libraries of the world immediately after the printing of each consecutive volume ${ }^{6}$ (the circulation figure of the first volume of SIRIO amounted to 2,400 copies). ${ }^{7}$ Owing to this, they became available to many generations of researchers, also outside Russia (and now they are even more accessible as they function in digitalized form).

${ }^{3}$ V. Kaplan states that the RIO was in fact subordinated to the Russian Ministry of Foreign Affairs, ibid., p. 98; the RIO's relations with government members are also mentioned by Mariia Iu. Agapova, 'Sborniki Russkogo istoricheskogo obshchestva kak istoricheskii istochnik', Russkii Istoricheskii Sbornik, 2, (Moscow) 2010, pp. 402-11 (p. 403).

4 'При подготовке материалов к публикации наиболее важным был принцип защиты государственных интересов', Agapova, 'Sborniki Russkogo', p. 405; similarly Kaplan, Historian and Historical, pp. 89-138.

${ }^{5}$ Available on-line 〈http://www.rulex.ru/xPol/index.htm〉 [accessed 29 March 2019].

${ }^{6}$ Agapova, 'Sborniki Russkogo', p. 408.

${ }^{7}$ The Sbornik had no commercial character, but the dictionary could be purchased 〈https://historyrussia.org/ob-obshchestve/istoriya.html〉 [accessed 29 March 2019]; Agapova, 'Sborniki Russkogo', p. 402. 
Both publications were tools of the politics of history of the Russian Empire at the turn of the nineteenth century.

Studying Polish-Russian relations in the second half of the eighteenth century, but also, in a broader way, the place of Polish issues in Russia's relations with its main European partners, I had to utilize the Sbornik almost incessantly. This article is an attempt at summarizing observations made during the use of diplomatic materials published by the RIO and comparing this edition with the original source documents. ${ }^{8}$

The need to summarize experience from reading SIRIO arose from the observation that some researchers feel by the very fact of its existence released from the duty to read/consult the archival resources which formed the basis of this edition. The most striking example of such an attitude is the study authored by Wolfgang Stribrny. He had free access to the archival basis of SIRIO, as he often used the resources of Berlin archives for his book about the Russian policy of King Frederick II of Prussia. Stribrny was critical of SIRIO, but gave no details. He wrote: 'the study of the Russian publication of documents, Sbornik of Imperial Russian Historical Society, is disappointing for our problem'. ${ }^{9}$ In spite of this, in regard to Prussian materials Stribrny, too, continued to rely on SIRIO, when he did not have the relevant documents of the correspondence of Frederick II published in the volumes of Politische Correspondenz Friedrich's des Großen (a few registers or abbreviated reports of Prussian envoys at foreign courts are in volumes 23-46, Berlin, 1896-1939; hereafter PC). Stribrny used archival manuscripts of Prussian diplomatic reports from St Petersburg only for the period not covered by the Sbornik. It is difficult to explicitly state whether such an attitude resulted only from the convenience of using the edition, or from a conviction that SIRIO was a good publication. There are also researchers who are almost enthusiastic about SIRIO. Thus, an outstanding expert in the history of early modern Europe, Hamish M. Scott, states that Prussian diplomatic reports from Russia, "have been printed in full in the volumes of SIRIO (vols XXII, XXXVII, LXXII), which is also an incomparable source for all aspects of Russia's foreign policy. ${ }^{10}$ One can also quote an opinion

${ }^{8}$ Agapova has also mentioned that SIRIO was worth analysing from a historiographical and editorial perspective, 'Sborniki Russkogo', p. 404.

9 'Enttäuschend ist für unsere Fragestellung das Studium der russischen Aktenpublikation, des Sammelwerks ("Sbornik") der Kaiserlich Russischen Historischen Gesellschaft', Wolfgang Stribrny, Die Russlandpolitik Friedrichs des Grossen 1764-1786, Würzburg, 1966, p. 240. Other examples of authors who have used SIRIO without any comment are Herbert H. Kaplan, The First Partition of Poland, New York and London, 1962; David L. Ransel, The Politics of Catherinian Russia: The Panin Party, New Haven, CT, 1975.

${ }^{10}$ H. M. Scott, The Emergence of the Eastern Powers, 1756-1775, Cambridge, 2001, p. 259. 
of a student of Russia's nineteenth-century academic environment: Vera Kaplan declares that materials published in SIRIO 'were edited according to the most rigorous contemporaneous archeographic standards'. ${ }^{11}$ But there are also historians, who - even if they were not sure - guessed that the use of the Sbornik required a critical approach. George T. Lukowski wrote that the 'Sbornik [...] passed through the Imperial censorship and there may well have been some mutilation of the original texts prior to the publication'. ${ }^{12}$ Władysław Konopczyński wrote in a similar tone with respect to the cooperation of the Russian diplomat Kasper Saldern with British diplomats: 'Traces of his [Saldern's - D.D.] selling himself to Englishmen, carefully removed from the Sbornik XII, XIX, we found in the R[ecord] O[ffice]. [...] Instead of these facts in the Sbornik, XII, pp. 458-59 there is Saldern's boast about rejecting Saxon offers'. ${ }^{13}$

It is noticeable that researchers differ in their assessment of SIRIO. This is why in this study I want to re-examine opinions appearing in later historiography, at least with respect to the Prussian diplomatic reports published in SIRIO as a sample. I would like to answer whether for the years covered by the edition they were published in a complete form. If not, what and how much of the base texts was published? What were the criteria of selection? Does that what was published meet the criteria of due diligence and being true to the original? Does it present a reliable picture of diplomatic agenda of Prussian-Russian relations? And - the most important thing - can a historian, who utilizes SIRIO, fully rely on the work of the nineteenth-century editors? As a student of the history of the eighteenth century I focus on the problems crucial for our knowledge of that period. Therefore, discussion relating to the circumstances of publication, including censorship, is marginal to the main current of my inquiry.

Before 1877 SIRIO volumes had - very much in line with the series' name - the character of a collection of different documents; after that

${ }^{11}$ V. Kaplan, Historian and Historical, p. 98; cf. an appreciation of the importance of SIRIO: Agapova, 'Sborniki Russkogo', pp. 409-10.

${ }^{12}$ George T. Lukowski, The 'Szlachta' and the Confederacy of Radom, 1764-1767/68: A Study of the Polish Nobility, Rome, 1977, p. 11.

13 'Ślady jego [Salderna - D.D.] zaprzedania się Anglikom, starannie usunięte ze Sbornika XII, XIX, odnaleźliśmy w R[ecord] O[ffice]. [...] Zamiast tych faktów dano w Sborniku, XII, s. 458-459 przechwałkę Salderna o odrzuceniu ofert saskich.' Władysław Konopczyński, Konfederacja barska, 2 vols, Warsaw, 1991, vol. 1, p. 141, note 29; similarly about the 'embarrassing cutting' of the dispatches of the British envoy in St Petersburg showing Saldern's venality, see Władysław Konopczyński, review of 'Brandt Otto: Caspar von Saldern und die nordeuropäische Politik im Zeitalter Katharinas II.', KH, 49, 1935, pp. 169-74 (p. 173). 
date SIRIO switched to publishing subject-focused (often multi-volume) collections of documents in six major groupings (for example, writings of Catherine II, materials on the history of 1812, materials for the history of Legislative Commission of 'New Order' from 1767). ${ }^{14}$ The personal patronage of successive rulers and Grand Dukes, as well as and contacts provided by the relations with the Ministry of Foreign Affairs facilitated obtaining copies of diplomatic materials from domestic and foreign resources. The above statement is particularly important, when we have in mind that one of the great SIRIO sub-series covered diplomatic correspondence of representatives of foreign countries in Russia. This sub-series included, among others, volumes of British, French, Austrian and Dutch diplomatic correspondence.

A great example of the implementation of the RIO's publishing policy is the edition of Prussian diplomatic materials from the period of the first partition of Poland, which is my main research focus. The edition illustrating the relations of Catherine II of Russia with one of her most important political partners - Frederick II of Prussia - was one of the first 'thematic' undertakings of the RIO, which indicates, among other things, the importance attached to this source evidence. ${ }^{15}$ It was an edition with specific goals set for it. In the introduction to subsequent 'Prussian' volumes one can read that the publication was intended to show the attitude of Prussia and other powers (in this context Austria was also mentioned) to the issue of reforms of the Polish political system, and of the Russian-Turkish war $1768-74$, as well as to explain the role of Prussia in the partition. ${ }^{16}$ As one of the specific aims the editors indicated showing King Frederick II of Prussia's insistence on incorporating Danzig (Gdańsk) into Prussia and Catherine II's resistance to the annexationist (and - let us add - aggressive) plans of her ally. ${ }^{17}$ It is worth adding here that in the second half of the nineteenth-century Russian historiography took for granted the interpretation of Solov'ev, who stated in 1863 that the collapse of Poland was an inevitable historical necessity. ${ }^{18}$ It only remained to point out the direct

${ }^{14}$ In the thematic volumes, the rule of publishing documents kept in one archive unit was often applied, Ol'ga V. Kamardina, 'Imperatorskoe Russkoe istoricheskoe obshchestvo: ocherk istorii i nauchnoi deiatel'nosti: 1866-1916 gg.', unpublished dissertation, Samara, 1999, 〈http://cheloveknauka.com/imperatorskoe-russkoe-istoricheskoe -obschestvo > [accessed 11 April 2019].

${ }^{15}$ The first was British correspondence published in vols 12 and 19, Kamardina, 'Imperatorskoe Russkoe'. The editors of SIRIO wrote about the meaning of Prussian correspondence in the introduction to vol. 22, pp. II-III.

${ }_{16}$ SIRIO, vol. 37, St Petersburg, 1883, pp. II-VI; vol. 72, St Petersburg, 1891, pp. I-III.

17 SIRIO, vol. 72, p. II.

${ }^{18}$ Sergei Solov'ev presented the concept of the collapse of Poland in his work 
factors which led to the collapse. The SIRIO edition certainly helped to highlight these factors. Similarly to Solov'ev's works, it set itself a task to release Russia from responsibility for the partition of Poland and point to Prussia as its initiator and the main executor. So we see how the activity of Russian historical science was correlated to accomplishing its political goals. ${ }^{19}$ Here we ask in what way the political goals of the edition affected its shape.

Material from of the Prussian Geheimes Staatsarchiv Preußischer Kulturbesitz in Berlin-Dahlem (hereinafter GStAPK) was published in volumes 22,37 and 72 of the Sbornik. It is mainly the correspondence of the Prussian extraordinary envoy and plenipotentiary minister at the Russian court from the period 1762-79, Victor Friedrich Solms, with his Berlin headquarters. Only part of the documents of Solms's mission was published, that is, the period 1763-74. The publication of Solms's correspondence was preceded by the edition (in volume 20) of letters of Catherine II and Frederick II from the period $1762-81 .^{20}$ The preparation of the 'Prussian' volumes of Solms's correspondence was entrusted to the RIO's long-term secretary, Georgii F. Schtendman. ${ }^{21}$ His collaborator was a Courland German, Ernst Adolf Herrmann (his name was transliterated into Russian as 'German' (Герман)), a historian and professor of the University of Marburg (from 1857), and a corresponding

Istoriia Padeniia Pol'shi published in 1863; Solov'ev's theory is discussed by Katarzyna Błachowska, 'Państwo, które ostać się nie mogło - spojrzenie historiografii rosyjskiej z drugiej połowy XIX w. na dzieje Polski', in W cieniu wojen i rozbiorów: Studia z dziejów Rzeczypospolitej XVIII i początków XIX wieku, ed. Urszula Kosińska, Dorota Dukwicz and Adam Danilczyk, Warsaw, 2014, pp. 499-522 (pp. 503-05).

${ }^{19}$ Błachowska, 'Państwo', pp. 499-522; on Solov'ev's works cf. also Dorota Dukwicz, Rosja wobec sejmu rozbiorowego warszawskiego (1772-1775), Warsaw, 2015, p. 18.

${ }^{20}$ Copies of monarchs' correspondence from the state archives of both countries were officially delivered by the Reich Chancellor Otto von Bismarck and the Russian Chancellor Aleksandr M. Gorchakov, which in practice meant that extracts were made at their order and maybe they approved texts for print: SIRIO, vol. 20, St Petersburg, 1877, p. V.

${ }^{21} \mathrm{He}$ was a member (from 1875), and then the secretary of the RIO (in the years 1879-1903); he was also a member of the Archaeographic Commission which published many source materials. In sum, he edited 31 volumes of SIRIO, $\langle$ https://historyrussia. org/ob-obshchestve/istoriya.html > [accessed 29 March 2019]; Aleksandr A. Polovtsov and Sergei D. Sheremetev, who managed the RIO's work, evaluated Schtendman's competences as a historian highly, and stressed that he was a student of Teodor Mommsen: V. Kaplan, Historian and Historical, p. 105; Ol'ga V.Belousova, 'Opisanie zasedanii Russkogo istoricheskogo obshchestva v dnevnikakh grafa S.D. Sheremeteva', in Gatchinskii dvorec $v$ istorii Rossii: Konferentsiia 1-3 dekabria 2016 goda priurochena $k$ 150-letiiu Rossiiskogo istoricheskogo obshchestva i 250-letiiu Gatchinskogo dvortsa, ed. Svetlana A. Astahovskaia and Elena V. Minkina, St Petersburg, 2016, pp. 38-48 (p. 39). 
member of the RIO (from 1871). ${ }^{22}$ Before he started to extract Solms's correspondence from the Berlin archives, he had cooperated with the RIO in copying diplomatic materials from archives in Dresden. ${ }^{23}$ It was Herrmann who prepared for publication extracts of source materials from Berlin, ${ }^{24}$ and Schtendman's role - I suppose - was limited to accepting (so probably - censoring) texts before printing. In the introduction to the first volume of Solms's correspondence (SIRIO, vol. 22) it is said that the RIO did not interfere in the selection of documents made by Herrmann. ${ }^{25}$ If we are to take this declaration at face value, it would mean that Herrmann was the one who implemented, in a small part, the Russian politics of history. But it is more likely that Schtendman or someone else censored the excerpts made by Herrmann.

The first 'Prussian' volume of SIRIO was published in 1878, and the next one in 1883. After publishing the third volume in 1891, bringing the edition of Prussian materials about to 1774 , Schtendman abandoned this series. ${ }^{26}$ Herrmann's death in 1884 was probably the main reason for not publishing Solms's correspondence from the period 1775-79. In the short, anonymous (not signed) introduction to volume 72 of SIRIO, a notice may be found that the materials of the Marburg professor were completed owing to the cooperation of Herbert von Bismarck, a former foreign

${ }^{22}$ Ernst Adolf Herrmann (born in Dorpat in 1812), previously a professor at Jena University; a student of Leopold von Ranke, he also cooperated in the edition of several other volumes of SIRIO (vols 3, 5, 6, 20) making excerpts of 'diplomatic materials for the history of Russia in the eighteenth century' from archives in Dresden; he also authored Geschichte des russischen Staates (vols 3-6, Gotha 1846-66), in the series: Geschichte des europaeischen Staaten, see Edmund Stengel, 'Herrmann Ernst Adolf H.', in Allgemeine Deutsche Biographie, vol. 55, 1910, pp. 489-93, 〈https://www.deutsche-biographie.de/ pnd124361080.html [accessed 23 April 2019].

${ }^{23}$ Given the shortcomings of the edition of Herrmann's Prussian materials discussed below, caution is also advisable when using his material from Dresden.

${ }^{24}$ I cannot say when exactly Herrmann worked in the Berlin archives, as I did not find his signature in the files' lists of the readers. In the introduction to volume 22 of SIRIO (1878), a mention can be found that the German scholar had made excerpts a few years earlier. In the introduction to volume 37 (1883), future publication of further materials was announced, with a declaration that the RIO had already gathered appropriate excerpts, SIRIO, vol. 22, p. I; vol. 37, p. V. So it is possible that Herrmann was commissioned to work in Berlin archives at the RIO's assignment in the mid-1870s, and quickly gathered material for three volumes, with volume 72 published only after the Herrmann's death, cf. note 25 below.

${ }^{25}$ SIRIO, vol. 22, p. IV.

${ }^{26}$ After abandoning of further work on Prussian correspondence, Schtendman personally took care of another series within SIRIO. Between 1881 and 1899 he published the largest sub-collection within SIRIO, consisting of 14 volumes, and covering the correspondence of French diplomats residing at the Russian court from the periods 1681-1733 and 1738-45. 
minister, and a son of the Reich Chancellor. ${ }^{27}$ It is possible that the RIO came to the decision that with the publication of materials up to 1774 (thus for the period of the first partition and the Ottoman war until the peace settlement) the aims of the edition were achieved. Thus there was no need to continue working on it. The open question remains whether the decision to stop the Prussian series of the Sbornik was influenced by the break in the Russian-German relations after Chancellor Otto von Bismarck's removal from office in 1890. An other important question to ask is how the tension in the Russian-German relations in the later 1870s could affect the shape of the source edition in question. Zofia Zielińska was the pioneer in noticing a correlation between the publication date of the first volume, the shape of source materials included therein, and the tension in Russian-German relations resulting from Germany's negative attitude towards Russia's territorial ambitions in the Balkans. ${ }^{28}$ I shall deal with this problem in the further part of the text.

Concerning the way of editing materials published in SIRIO, one of the preliminary rules of the whole edition was to publish foreign-language sources in the original with concurrent translation into Russian, and with addition of comments within the scope which RIO members considered necessary. ${ }^{29}$ Each editor decided on his own about the selection of sources to be published.$^{30}$ Besides these very general rules, the RIO did not develop any uniform strategy of selection and conventions of edition of materials for the subsequent volumes of the Sbornik. Mariia Iu. Agapova correctly observes that the majority of diplomatic correspondence was published in SIRIO without any comments (either in the form of introduction or footnotes), without marking omissions, sometimes with the use of method of summarizing (regesting) fragments of text but without marking a switch from the original text to the résumé (regesta), and chronology was the only factor deciding about the order of documents in particular volumes. ${ }^{31}$

${ }^{27}$ SIRIO, vol. 72, p. I.

${ }^{28}$ Zofia Zielińska, Polska w okowach 'Systemu Północnego' 1763-1766, Cracow, 2012, p. 331.

${ }^{29}\langle$ https://historyrussia.org/ob-obshchestve/istoriya.html〉 [accessed 29 March 2019]; Agapova, 'Sborniki Russkogo', p. 405.

${ }^{30}$ Agapova, 'Sborniki Russkogo', p. 405. Agapova also notices that particular volumes of SIRIO differ regarding the content and scope of introduction, arrangement of the table of contents or accuracy of descriptions of entries in indexes, ibid., pp. 407-08; inconsistency in the way of elaborating sources, and especially shortcomings of the critical apparatus accompanying volumes of political correspondence of foreign residents at the Russian court, were also mentioned by Kamardina, 'Imperatorskoe Russkoe'.

${ }^{31}$ Agapova, 'Sborniki Russkogo', p. 406; an exception is the British correspondence, here the editors indicated that the person making excerpts omitted generic confirmations of receipt of earlier letters, as well as information on the names of the couriers, 
Due to this, in most cases the reader was deprived of the possibility to follow the scale of editorial interventions in the text of the source. Along with the main rule of serving the interests of the state there was also a special kind of censorship, illustrated by a passage from the introduction to the first volume of English correspondence quoted by Agapova (SIRIO, vol. 12, p. VI): 'only a small number of writings was put away [in the sense of not published - D.D.], those which contained almost exclusively unpleasant gossips on the details of family life of well-known persons'. ${ }^{32}$ Ol'ga Kamardina wrote simply: 'The main rule of selection of documents for publishing was a ban on publication of documents discrediting persons or governments' ${ }^{33}$ Thus in addition to the aforementioned aspect of serving the interests of the state, the editors applied social-ethical-political censorship. It was applied - as in the case of British correspondence both by those who controlled the copied material of excerpts from foreign archives before submission to the RIO, and the Russian editors. In the case of British diplomatic correspondence, the names of the Russian censors were placed in the introduction to the first volume and they were credited for their work. ${ }^{34}$

So what does the publication of Prussian diplomatic correspondence in SIRIO look like? A short, unsigned introduction to the first volume of Prussian materials contains no description of the 'system' which Herrmann adopted when making excerpts. There is only brief information that the volume gathers 'extracts' (izvlechenia) from Solms's correspondence and a small number of such extracts from the royal instructions for the envoy. ${ }^{35}$ And in the introduction to volume 37 of SIRIO (the second volume of Prussian correspondence) only 'despatches' and 'instructions' are mentioned without any clarifications regarding to publication of the source texts in full or in part. ${ }^{36}$

about possible problems faced by the courier while carrying diplomatic mail. Those details were excluded as the editors considered them not interesting; omissions were signalled by the word 'extract' at the head of the letter: SIRIO, vol. 12, St Petersburg, 1873, p. VI. And as far as chronological arrangement of texts is concerned, it is sometimes distorted in the Prussian material, see the publication of the fragment of the report dated 27 January 1769 after texts dated February of that year: SIRIO, vol. 37, pp. 211-13.

32 'Отложено лишь весьма незначительное число бумаг, содержавших почти исключительно неблагоприятные слухи о подробностях семейной жизни известных в то время лиц’, Agapova, ‘Sborniki Russkogo', p. 405.

33 'Основным принципом отбора документов к печати был запрет к публикации документов, компрометирующих лиц или правительства в целом', Kamardina, 'Imperatorskoe Russkoe'.

${ }^{34}$ SIRIO, vol. 12, pp. VI-VII.

35 SIRIO, vol. 22, p. I.

${ }^{36}$ SIRIO, vol. 37, p. I. 
I could see the real scale of censors' and editors' interventions in the original text of the Prussian material and the 'system of professor Herrmann' ${ }^{37}$ only through comparing correspondence published in SIRIO with original files kept in the GStAPK. I made such a detailed inquiry in the Prussian diplomatic materials for the period 1768-73 for the purpose of studying the Polish problem in Russo-Prussian relations. During my queries I was able to compare what had been published in SIRIO with what was preserved in the archive. For the beginnings of Solms's mission I followed the observations of Zielińska, who has, so far, most fully discussed the problem of incompleteness of the Prussian diplomatic correspondence published in SIRIO. ${ }^{38}$

Already the proportion between what was published and what was not shows how the politics of history was applied to the publishing process of SIRIO. The early years of Solms's mission are reflected in SIRIO very moderately. In the period 1763-67 Solms sent to Berlin 412 numbered reports, of which only 167 reports were published in SIRIO (volumes 22 and 37). That constitutes 40.5 per cent of the whole correspondence. Within this period the overrepresentation of reports from 1763-64 is clearly noticeable (105 in total, of which 61 are from 1763 and 44 from 1764) ${ }^{39}$ These were the years when the fate of the Russian-Prussian alliance was at stake; that alliance becoming an axis of the 'Northern System' being a basis of Russia's imperial position in Europe, and when Petersburg decided about the cast of the Polish throne and the fate of King Stanislaw August's first reforms.

Analysing the material from the years 1763-64, Zielińska noticed that the editors omitted the evidence of Russia's efforts to get a Prussian co-guarantee regarding the Polish political system. 'The lack of this portion in the publication of Solms's reports [...]' - as Zielińska points out - "is one of the examples of incompleteness of this edition, and probably also of the trend of its "cleansing" of undesirable informa-

37 This expression was used by the Russian editors: SIRIO, vol. 22, p. IV.

${ }^{38}$ With respect to Prussian ministerial rescripts Zielińska noticed that 'their publication in SIRIO covered a small fragment of what [ministers] really sent' ('ich publikacja w SIRIO obejmowała niewielki fragment tego, co naprawdę [ministrowie] wysłali'). And in the detailed references to Solms's reports Zielińska signalled the need to use archive materials due to the incompleteness and errors in the edition, Zielińska, Polska, pp. 10, 14, 38 (note 84), 330-31; cf. her comments on the incompleteness of the SIRIO edition: Zofia Zielińska, Studia z dziejów stosunków polsko-rosyjskich w XVIII wieku, Warsaw, 2001, p. 83, note 91.

${ }^{39}$ For other years from that period the number of Solms's reports published in vols 22 and 37 of SIRIO is as follows: 1765: 12, 1766: 30, 1767: 20. 
tion'. ${ }^{40}$ This is an example of deliberate manipulation of the source text. We are faced with the omission of information proclaiming that Russia did not feel strong enough in Poland and tried to get Prussian assistance, which was particularly important in the context of the upcoming Polish royal election. Zielińska's observations regarding censoring in SIRIO the issues related to Russia's attitude to Polish-Prussian dispute over the general customs duty in 1765 are even more interesting. The general customs duty was one of the first important reforms of the new king of Poland, which was supposed to secure a stable and rich source of income to the state. It was to contribute to the reconstruction of economic sovereignty and to be an element of sorting out the legal and economic order. ${ }^{41}$ Zielińska mentioned the omission (in volume 22 of the Sbornik) of the demonstration that in the dispute, in which St Petersburg considered itself to be in a position of power, Russian policies had to yield to German pressure. 'The edition was deprived of all [...] evidence of St Petersburg's acquiescence to Berlin's demands. [...] Still, there was no problem with publishing texts showing the effective pressure of Russia on Prussia'. ${ }^{42}$ As an example it is worth referring to the detailed findings of Zielińska, who showed, that of Solms's report from January only 1765 the beginning of the paragraph on the duty issue was published. The text as published in SIRIO creates a false impression of full Russian support for the activity of Frederick II attacking the economic sovereignty of Poland: 'D'ailleurs le comte [Nikita I.] Panin m'a assuré positivement, qu'il avait parlé au comte [Franciszek (Polish representative in Petersburg - D.D.)] Rzewuski sur les griefs formés de la part de Votre Majesté contre les nouvelles douanes [general customs duty - D.D.] et qu'il l'avait chargé d'écrire au nom de Sa Majesté l'Impératrice au roi de Pologne pour rectifier le passé. ${ }^{43}$ As Zielińska writes

40 'Brak tej partii w publikacji relacji Solmsa [...] stanowi jeden z przykładów niekompletności owej edycji, a prawdopodobnie też kierunku jej “czyszczenia” z niepożądanych informacji',Zielińska, Polska, p. 166, note 28; see another omission in Solms's report signalled by her, which evinces the Polish side's conviction about the co-dependence of Russian and Prussian decisions regarding permission for reforms in Poland, ibid., p. 234, note 155.

${ }^{41}$ The latest study on this problem is the chapter of Zielińska, Polska, pp. 256-374, titled: 'Rosja wobec polsko-pruskiego sporu o cło generalne'.

${ }^{42}$ 'Z $Z$ edycji usunięto wszystkie [...] świadectwa spolegliwości Petersburga wobec Berlina. [...] Nic za to nie przeszkadzało publikowaniu tekstów świadczących o skutecznej presji Rosji na Prusy'. Comprehensively on this subject, see Zielińska, Polska, pp. 330-31.

${ }^{43}$ Victor F. Solms to Frederick II, 11/22 January 1765, SIRIO, vol. 22, p. 357. Since the goal of this article is not an analysis of the content of the quoted source fragments, but rather showing examples of manipulation with the source text by SIRIO's editors, I resign from providing translations of the highlighted passages of Solms's correspondence. 
'in fact the further part of the report [...] proves something opposite'. ${ }^{44}$ she discussed the missing fragment of the report, from which it follows that the head of Russian foreign policy, Nikita I. Panin, hoped that after obtaining satisfaction from Polish side Frederick II would allow the Poles to introduce the general customs duty, which - the Russian minister was sure - per saldo would prove beneficial not only for the Polish side but also for the Prussian. It also holds true for an omission of information on Russian activity which was supposed to force Prussia to end the dispute about the duty and the critical remarks of Panin on the conduct of the Prussian resident in Danzig. In printed version, as Zielińska states, 'there is only a fragment showing Panin's intents to consolidate the Prussian-Russian alliance, this time preceded by an ellipsis proving that not the whole report was published'. ${ }^{45}$

Having mentioned the time-correlation of the publication of the SIRIO volume in question with an unleashing of anti-German hysteria caused by Berlin's objection to Russian aspirations on the Balkans, Zielińska states: 'I guess that in this atmosphere the editors decided not to reveal the full truth about the times when Russia and Prussia enjoyed friendship, the profits of which - thanks to St Petersburg's power - were also available to Berlin' ${ }^{46}$ She also mentions the omission of the instruction for the Russian envoy in Warsaw of 31 July 1765 in SIRIO's volume 57 (1887), which probably resulted from the same motivation. This document ordered the diplomat to pretend readiness to fulfil Prussian requests regarding the general customs duty, something which - Zielińska supposes - proved unpublishable in the 1880s.

It is true that in 1887 anti-German moods in Russia were far more relaxed as compared to the situation several years earlier, but relations between Berlin and St Petersburg were not friendly. [...] I believe that the editors of SIRIO 57 did not want to publish the text, which for the

44 'W rzeczywistości dalsza część raportu [...] dowodzi czegoś przeciwnego', Zielińska, Polska, p. 267, note 46.

45 'Jest wyłącznie passus świadczący o intencjach Panina scementowania przymierza prusko-rosyjskiego, tym razem poprzedzony wielokropkiem dowodzącym, że nie cały raport opublikowano', ibid., p. 317, note 256. Another example of censoring the general customs duty question, ibid., p. 329, note 316. Generally, about the editors' censorship of information about the defence - until a certain time - of the Polish customs duty act and attempts to persuade Prussian king Frederick II to accept it, or on Russian disapproval for Berlin's negative position on the issue, ibid., p. 331.

46 'Domyślam się, że w tej atmosferze wydawcy postanowili nie ujawniać pełnej prawdy o czasach, kiedy Rosja i Prusy żyły w przyjaźni, której profity - dzięki potędze Petersburga - zbierał także Berlin', ibid., p.331. 
readers not aware of the nuances could seem pro-Prussian, and would seem contrary to what they could have read in Solms's reports nine years earlier. ${ }^{47}$

This is a very important comment, which indicates existence of the considered, consistent and long continued editorial line of the RIO.Zielińska's findings impose on other researchers the need for a very critical approach to the remaining, 'not-Prussian' volumes of SIRIO.

Going back to the Prussian reports, I can say - based on my archival observations - that between 1768 and 1773 Solms sent 544 numbered diplomatic reports (from no. 413 to no. 956) from St Petersburg to Berlin, and a certain number of unnumbered letters. ${ }^{48}$ Of this collection, 221 letters were published in volumes 37 and 72 of the Sbornik (including 18 as extracts (izvlechenia), and from one postscript (P.S.) only, which, however, does not mean that the remaining texts were published unabridged). This constitutes approximately 40.5 per cent of all Prussian reports from St Petersburg in the period I focus on (so it is the same ratio as for the earlier period). In detail we will see the clear disproportion of publication's fullness for particular years. For 1768, 15 reports (of 77 sent) were published, for $1769-30$ (of 95 sent), for 1770 - only 19 (of 80 sent), for 1771 - 37 (of 93 sent; in one case it was stated that only a postscript had been published), for $1772-87$ (of 97 sent; 8 of them with the heading 'extract'), for $1773-33$ (of 97 sent, again 10 were published as 'extracts'). This simple calculation shows clearly that for the years 1768-71 and 1773 the editor applied a harsh selection of material. Only the year 1772, when the partition negotiations were finalized in St Petersburg, was worth attention and effort, and almost 90 per cent of the reports from that period were published, whereas a large part of information on implementation of partition and finalization of the Turkish war was not included.

As far as publication of dispatches sent from Berlin to St Petersburg is concerned, the picture is even worse. For the year 1768,7 royal instructions

47 'W prawdzie w 1887 r. nastroje antyniemieckie w Rosji, w porównaniu z tym, co było kilka lat wcześniej, uległy znacznemu złagodzeniu, ale stosunki między Berlinem a Petersburgiem nie były przyjazne. [...] Jak sądzę, wydawcy SIRIO 57 nie chcieli ujawniać tekstu, który dla niezorientowanych w niuansach czytelników mógł brzmieć filoprusko i być sprzeczny z tym, co wynosili oni z lektury wcześniejszej o 9 lat edycji raportów Solmsa'. Comments on SIRIO, vol. 57: Zielińska, Polska, pp. 331-32, 371 (with indication of particular omissions in the edition).

${ }^{48}$ Original dispatches of Solms to Frederick II from the period 1768-73 are now in the GStAPK, Hauptabteilung 1., Repositur 96: Geheimes Kabinett, ältere Periode (hereafter 1.HA, Rep. 96), file nos. from 57A to 58C. 
and 8 ministerial ones were published in SIRIO, for 1769, 8 letters of Frederick II to Solms only and one ministerial instruction were published, for 1770 the numbers are, respectively, 11 and 9, for $1771-26$ royal instructions for Solms and 46 ministerial letters, plus royal instructions for recipients other than Solms, for $1772-16$ instructions of Frederick II and 12 ministerial ones for Solms, as well as 3 royal instructions for other recipients, for $1773-5$ royal instructions and 1 ministerial. A similar numerical disproportion cannot be observed for royal and ministerial letters in particular years.

The proportion of letters sent from Berlin in 1771 to those sent from St Petersburg is remarkable (seventy-two to thirty-seven). I believe that such proportions for the year in which secret negotiations regarding the partition of Poland were concluded resulted from a deliberate reflection. In my opinion such a choice of material to publish was to conceal the real involvement of both parties in the negotiations, and to highlight Prussian activity. An example of an important omission barring the reader from understanding the actual position of both states about the issue of partition is Solms's dispatch of 8 March 1771. This is a response to the bestowal upon Solms of the plenipotentiary powers granted to negotiate the territorial range of partitions. It contains a fragment 'C'est la plus grande satisfaction pour moi, que j'ai reconnu dans les premiers la gracieuse marque de confiance dont elle [Votre Majesté = Frederick II - D.D.] veut bien m'honorer, en me chargeant de négocier ici pour l'acquisition de quelque partie de la Pologne pour Votre Majesté. Il serait trop présomptueux a moi, Sire, de m'engager a vous promettre de tirer de la cour de Russie en tres peu de tem[p]s une résolution décisive, et telle que vous pourriez la desirer' ${ }^{49}$ This fragment clearly shows that Prussia was active in trying to acquire territories of Poland, but everything ultimately depended on the Russian decision.

It is worth adding that one may bypass the deficiencies of SIRIO by using the aforementioned $P C$, well-known to most researchers in the field. ${ }^{50}$ To show the context of the letters of Frederick II, the editor, Gustav B. Volz, used to quote from time to time substantial portions fragments of letters, to which the Prussian king replied. Thus, the $P C$ also contains quotations sometimes extensive - from Solms's reports. ${ }^{51}$ But first of all, owing to the

${ }^{49}$ Solms to Frederick II, 25 February/8 March 1771, GStAPK, 1. HA, Rep. 96, 57F, no. 684. A fragment of this dispatch (but not containing this quotation) was published in PC, vol. 31, Berlin, 1906, p. 38.

${ }^{50}$ It concerns the relevant volumes of $P C$ (for years 1769-73 these are vols 28-34), ed. Gustaw B. Volz, Berlin, 1903-10.

${ }^{51}$ As an example one can refer to Solms's report of 23 December 1768/3 January 
$P C$ we have almost complete political correspondence of Frederick II (including instructions for Solms), except for those documents, which were detached by the Prussian chancellery and included the 'secretissima' category, as well as some specific documents which may have been put under separate subject headings. ${ }^{52}$ Anticipating the final conclusions it is worth adding that when compared to SIRIO, the Prussian edition is a model one. The vast majority of documents have been published in full and without errors. If the editors omitted anything, the omission was signalled to the readers in the text. Having compared that edition with the archive material I am not able to indicate significant flaws. That shows that already at the turn of the ninetenth century the editorial standards could be very high, fully comparable to today's norms of editing historical documents. Therefore, the incompleteness of Prussian royal instructions in detail and the quality of what was published in SIRIO in general poses no problem for researchers. Another issue which Zielińska mentions is the restricted scale of publishing ministerial correspondence, that is, letters and instructions sent to Solms by the cabinet ministers, Ewald Friedrich Hertzberg and Karl Wilhelm Finckenstein. ${ }^{53}$ Here researchers need to use the holdings of the GStAPK. Obviously, the ministers provided explanations to the envoy within the limits defined in the king's despatches, but these extended explanations sometimes valuably make the laconic royal instructions more precise.

So what should be said about the way in which documents from Prussian diplomatic correspondence were published in SIRIO? The basic text in French, accompanied by the Russian translation, is usually

1769 not included in SIRIO, from the period when Prussia and Russia began negotiations regarding the renewal (in practice extension) of the alliance. The Prussian envoy forwarded to Berlin a Russian request for defining terms of Prussia's allied involvement in the Russian-Turkish war. It was very important for St Petersburg to get a declaration of what could be expected from Berlin, and Russia was satisfied to accept the Prussian proposal of a renewal of the alliance. An extensive, the most important and originally fully encoded fragment of Solms's letter, omitted from SIRIO, was published in PC, vol. 28, p. 41-43; Solms to Frederick II, 23 December 1768/3 January 1769, GStAPK, 1. HA, Rep. 96, 57B, no. 490.

${ }^{52}$ An interesting, but isolated example of letter absent in PC, vol. 29, is Frederick II's instruction for Solms dated 27 November 1769, in which the king complained that the payment of subsidies for Russia for the war with Turkey was a problem due to the differences in the exchange rate and proposed to determine a fixed exchange rate advantageous for both countries. He also demanded that Catherine II consult expenses with him and present invoices, if she wanted to allocate Prussian subsidies to the needs of the Russian army in Poland or other purposes not directly connected with the Turkish war: GStAPK, 1. HA, Rep. 96, no. 57C, fol. 302. This letter was not published by SIRIO either, which fits in the policy of hiding Russia's dependency on its Prussian ally, adopted by the RIO.

\footnotetext{
${ }^{53}$ See note 38 above.
} 
accurate. Each letter has its collection number, not connected with the signatures given by the Prussian chancellery or the envoy in St Petersburg. The entries' headings contain information about who wrote a letter, and to whom, where it was issued, and show its date. In the case of letters sent from Russia, documents are provided with two dates, according to the old and new style. Certain letters have a chancellery receipt and a stamp, but this is not a rule. And this is the whole apparatus which describes the sources. In the majority of cases the editors did not mark which parts of letters were encoded and which were not. In almost every report Solms encrypted those fragments which he considered significant, and left minor information open. This was important, because diplomatic correspondence was usually delivered by ordinary mail, not by military couriers. In the majority of the published texts confirmations of the receipt of successive letters, which were placed at the beginning of letters, are omitted (it is important as the authors usually referred to the letters they received by the latest mail and commented the issues mentioned in those letters). Thus, these confirmations not only would enable researchers to define the chronology of correspondence, but also tell them about what information the author possessed when he wrote each letter.

Besides the aforementioned gaps and omissions the researcher using the 'Prussian' volumes of SIRIO faces other problems. As signaled above, first and the most important is that - the readers are not informed whether they deal with edition of the whole, unabridged text, a fragment, or a document partly or fully regested (summarized), since as a rule there is no sign that certain fragments of letters have been omitted in the edition. ${ }^{54}$ The absence of courtesy expressions at the beginning or at the end of the letter (often omitted by SIRIO editors) can-

${ }^{54}$ Many cases of omission of substantial fragments, without marking it in the text of ministerial letters to Solms (SIRIO, vol. 22, pp. 323, 349, 381-82) are indicated by Zielińska, Polska, p. 252, note 224, p. 253, note 235, p. 315, note 247. Also, an example of significant omissions in the envoy's reports is Solms's report of 14 October 1766 (SIRIO, vol. 22, p. 494) regarding the reaction of St Petersburg to the downright refusal of concessions in the dissenters' case by the Poles, Zielińska, Polska, p. 555, note 22; see also ibid., pp. 565-66, notes 58,59,62. Zielińska also mentions examples of source texts, which in SIRIO are broken in the middle of the sentence, as if the person making the extract got tired and did not finish work after a break, see Zielińska, Polska, p. 69, note 137 , p. 287 , note 125 . As one of many examples I came across I can add the omission of a phrase indicating the real scope of Prussian appetites for Danzig (omission in bold). 20/31 December 1771 Solms wrote: 'Pour ce qui regarde la ville de Dantzig je ne manquerai pas de faire une tentative afin d'obtenir pour V.M. le droit territorial sur cette ville, de la manière qu'il a été exercé par les rois de Pologne, me réservant de faire mon très humble rapport de ce que j'aurais pu effectuer.' SIRIO, vol. 37, p. 582; see Solms to Frederick II, 20/31 December 1771, GStAPK, 1. HA, Rep. 96, 57H, no. 760. 
not be a guideline for readers. Only in some letters can one guess that it is a regesta, when the author of the text appears in the third person, and a note is partly written in a language different from the source language. An example of this type of editorial practice is the German beginning of Solms's second report from January 1769, which nota bene opens the edition of correspondence from that year (the first letter was omitted): 'Solms berichtet über Massregeln, welche mann nimmt, pour la guerre contre les Turcs' ${ }^{55}$ Here - thanks to the German language insertion - the reader is certain that Herrmann omitted the beginning of the report.

It also happens that French insertions like 'contenu de cette dépêche' or the very 'contenu' itself signal a summarizing of the fragments of correspondence..$^{56}$ But the reader is not always able to differentiate the French summary from the source text. Solms's aforementioned report of

55 Solms to Frederick II, 26 December 1768/6 January 1769, SIRIO, vol. 37, p. 190. For a one-sentence German summary of the letter, without publication of any fragments, see Finckenstein and Hertzberg to Solms, 10 December 1768, SIRIO, vol. 37, p. 183. Also cf. SIRIO, vol. 37, pp. 207, 229. Sometimes the reader meets such German abstracts in the middle of the text. For example: in the French text of Solms's letter to Frederick II of 6/17 January 1769 half of the sentence is in German: 'Die Kaiserin wünscht mehr, que V.M. put fournir', SIRIO, vol. 37, p. 195; analogically, SIRIO, vol. 37, p. 238. But sometimes the sense of German insertions is completely incomprehensible and misleading, such as when expression 'de la pacification' referring to Russian-Turkish negotiations, was for some reason replaced with a German insertion: 'J'ai rendu compte à S.A.R. Monseigneur le prince Henri de tout ce qui regarde cette affaire (den türkischen Krieg)', Solms to Frederick II, 5/16 October 1770, SIRIO, vol. 37, p. 318; cf. GStAPK, 1. HA, Rep. 96, 57E, no. 649.

${ }^{56}$ For example, Solms to Frederick II, 14/25 May 1770, SIRIO, vol. 37, p. 292, here after publishing a part of text an expression 'contenu de cette dépêche' was inserted, and next the rest of the report was summarized in two points. Sometimes this 'contenu' published instead of the text of report was constructed in a way aimed at convincing the reader that the omitted letter is completely meaningless: 'Contenu: Dépêche en réponse à quelques articles de l'ordre du roi; elle ne contient que des choses vagues de peu de conséquence.' Solms to Frederick II, 27 December 1771/7 January 1772, SIRIO, vol. 37, p. 588. In fact, the summarized report of Solms from the time of finalizing the secret Russian-Prussian convention on the partition of Poland contains interesting information on Prussian pressure on Russia, exerted until the last minute concerning the precise territorial scope of Prussian partition: 'On n'a pas nommé ici la ville d'Elbing expressément dans le traité, quoique je l'avais demandé, parce qu'on a cru, qu'il était superflu de la nommer et que sous les paroles de Marienbourg et l'évêché de Warmie, sans en rien exclure, elle était suffisamment comprise; cependant si V.M. l'ordonne, il sera aise de remédier à cette omission dans l'expédition de l'instrument', Solms to Frederick II, 27 December 1771/7 January, GStAPK, 1. HA, Rep. $96,57 \mathrm{~J}$, no. 762. This omission is incomprehensible, because in the subsequent ten reports relating to the conclusion of the partition negotiations all fragments related to this problem were published in SIRIO in full. 
6 January 1769 ends in SIRIO with the following sentence: 'Après les affaires de Turquie ce sont celles de Suède, qui dans le moment présent attirent le plus l'attention de la cour de Russie. ${ }^{57}$ This French sentence looks as if written by Solms, but in fact it is a kind of synopsis of a larger fragment about attempts to obtain Prussian support for the declaration which St Petersburg planned to publish in connection with affairs of Sweden being an element of the Russian 'Northern System', where Russian interests were jeopardized. A declaration which the Prussian envoy presented was supposed to express a Russian protest against the plans of King Adolf Frederick to change the Swedish status quo in order to regain sovereignty. Thanks to Solms's report we know that Panin cared about the cooperation of Frederick II, especially since the recent renewal of Prussian-French diplomatic contacts had given the pro-French and anti-Russian party in Sweden an opportunity to undermine the stability of the Russian-Prussian alliance. Therefore Russian diplomats in Sweden, who were in a weak position, needed Prussian support, but the editors of SIRIO did not include this information, and did not inform readers about their decision to omit it.

Problems related to Russia's policy towards Sweden were undoubtedly subject to censorship. The crowning proof of the avoidance of informing the readers about the crisis of Russian domination in Sweden in late 1768 and early 1769 is the next report by Solms from January 1769. In the Russian edition only one incomplete sentence is published, which gives impression of a condescending tone of Russian persuasion addressed to the Prussian king, aimed at persuading him to counteract Swedish attempts to regain sovereignty. ${ }^{58}$ In fact - as can easily be discovered from the $P C$ where a substantial fragment of this important text is reproduced - Solms's report shows Russia's frantic search for support - diplomatic, military and financial, from Prussia, Denmark and Great Britain, to balance French influences at the Swedish court, and, more broadly, to save

${ }^{57}$ Solms to Frederick II, 26 December 1768/6 January 1769, SIRIO, vol. 37, p. 194.

58 'Il (le comte Panin) est persuadé que V.M. ne voudra pas permettre qu'il se fasse dans la constitution de la Suède un changement qui donnait la souveraineté au roi, ou qui fit prendre de manière ou d'autre là-dessus à l'influence de la France.' Solms to Frederick II, 30 December 1768/10 January 1769, SIRIO, vol. 37, pp. 194-95. For analogous censoring of information on Swedish issues, without marking omissions in the text, see Solms to Frederick II, 16/27 January 1769, SIRIO, vol. 37, pp. 211-13; cf. Solms to Frederick II, 16/27 January 1769, GStAPK, 1. HA, Rep. 96, 57B, no. 497; there are also whole reports on the Swedish crisis omitted from SIRIO and not quoted in PC, for example Solms to Frederick II, 18/29 December 1768, GStAPK, 1. HA, Rep. 96, 57A, no. 488; or an interesting letter, in which Solms included a Russian request to transfer part of the subsidies for the war with Turkey to Sweden, Solms to Frederick II, 27 February/10 March 1769, GStAPK, 1. HA, Rep. 96, 57B, no. 509. 
the stability of the 'Northern System'.${ }^{59}$ We see therefore that the editors of SIRIO decided that the moment of weakness of Russian policy at the beginning of 1769 should be hidden from readers. It is interesting that in the materials from the second half of the same year, when Turkish problems began to dominate in Russo-Prussian relations, the Swedish question, already a secondary one, practically ceased to be censored, that is, it was not omitted from the few published reports from that period. After the renewal of the Russo-Prussian alliance in October 1769 and the temporary backdown of Russia in Sweden, the 'Northern System' again began to stabilize, so probably this is why the editors of SIRIO thought that news from Sweden from that period would not contribute to the disclosure of hesitations and weaknesses in the policy of the Russian Empire.

Another example of censorship of content - this time less important -is Minister Panin's attitude to the Bar Confederacy. In Solms's report of 17/28 June 1768 the French text was introduced with a German-language notice 'Solms hat Panin gesprochen', which replaced a short introductory description that the meeting of Prussian diplomat with the minister had taken place in Tsarskoe Selo, during 'an open day' ('un jour de cour public à la campagne'). ${ }^{60} \mathrm{Also}$, in the following paragraph the editors removed a fragment in which Solms referred to his conversation with Panin about the latter's criticism of a Russian commander who had proved inefficient in fighting the Bar confederates. The omitted fragment in the original version is as follows: 'Il [Panin - D.D.] m'a fait connaitre, que son opinion etoit encore toujours celle-ci, que pourvu que l'armée russienne puisse atteindre les confédérés [of Bar - D.D.] dans leur siège capital, ces derniers seraient bientôt forcés de se soumettre, et que la tranquillité serait alors rétablie pour toujours dans la République' ${ }^{61}$ One may ask about the reasons for removing from the text the fragment revealing the conviction of the head of Russian foreign policy that the Bar Confederacy could easily be defeated. Was the text censored because Panin was absolutely wrong in his expectations, and overcoming the confederacy proved far from easy, requiring much time and effort on the part of Russia? It is difficult to answer unequivocally, but one can note that none of Solms's earlier reports, relating Panin's disregard towards the Bar Confederacy and his conviction that it was not a problem for Russia was printed in SIRIO. ${ }^{62}$

${ }^{59}$ Cf. PC, vol. 28 , pp. 64-66.

${ }^{60}$ Solms to Frederick II, 17/18 June 1768, SIRIO, vol. 37, pp. 157-58.

${ }^{61}$ Solms to Frederick II, 17/18 June 1768, GStAPK, 1. HA, Rep. 96, 57A, no. 446.

${ }^{62}$ An example: unpublished fragments about the Russian government's attitude toward the Bar Confederacy in the first phase of its existence: 'Je [Solms - D.D.] ne 
An interesting example of a kind of promotion of information for publication is the so-called Lynar plan. In the historiography this plan, presented by Frederick II, has been treated as a partition survey proving Prussian initiative in the partition of Poland. ${ }^{63}$ It is probably the best known aspect of Russo-Prussian relations in 1769. In my opinion researchers still ascribe too much significance to this problem; this emphasis results from an extensive illustration of this question by source editions, including SIRIO, and - in consequence - from its place in the older literature on the subject. The historian Albert Sorel is perhaps responsible more than any other scholar for this state of the question, as his work La Question d'Orient au XVIII siècle determined for generations the way of writing about the first partition. ${ }^{64}$ It is important for subject discussed here that Sorel based his reconstruction of the Prussian and Russian policies on the RIO's publications. ${ }^{65}$ The editors of the fragments of Prussian diplomatic correspondence from the first half of 1769 clearly emphasized the issue of the Lynar plan publishing the whole letter of Frederick II of 2 February 1769, containing this proposal and a substantial fragment of Solms's response. ${ }^{66}$

We meet similar, although less important, examples showing that the editors of SIRIO artificially created the agenda of Russo-Prussian diplomatic relations in other places. My case may be illustrated by Solms's reports from the spring of 1768 (from March to June, reports numbered 424

saurais m'imaginer cependant, qu'on ignore ici la situation véritable des premières [Bar confederates in Poland - D.D.]. Il me semble au contraire, qu'on veuille, ou s'étourdir là-dessus, et ne pas les regarder de conséquence, puisqu'on espere pouvoir les terminer, ou qu'on veut cacher au public l'impression qu'elles font', Solms to Frederick II, 20/30 May 1768, GStAPK, 1. HA, Rep. 96, 57A, no. 441; 'Il [Panin] a tiré la conclusion, que la supériorité des armes de Russie l'emporterait infailliblement sur les efforts que les mécontents pourraient faire', Solms to Frederick II, 27 May/7 June 1768, GStAPK, 1. HA, Rep. 96, 57A, no. 443.

${ }^{63}$ For example: Stribrny, Die Russlandpolitik, p. 49; H.H. Kaplan, The First Partition, p. 112; Isabel de Madariaga, Russia in the Age of Catherine the Great, London, 2002, p. 221.

${ }^{64}$ Albert Sorel, La Question d'Orient au XVIIIe siècle: le partage de la Pologne et le traité de Kaïnardji, Paris, 1877 (1st edn), Paris, 1889 (2nd edn; pp. 45-48, here about the Lynar plan and the Prussian partition initiative).

${ }^{65}$ Sorel, La Question, Paris, 1889, p. IV (here information that the first edition was supplemented with (inter alia) materials from SIRIO).

${ }^{66}$ Frederick II to Solms, 2 February 1769, SIRIO, vol. 37, p. 204 (cf. minor differences in reading: $P C$, vol. 28, p. 84); for the envoy's response in the form of an encoded postscript devoted to this matter, see Solms to Frederick II, SIRIO, vol. 37, pp. 215-18 (here the non-encrypted portions of the letter containing, among other things, information about Russian victories over the Bar confederates in the Wielkopolska [Greater Poland] region were omitted in print); from this postscript by Solms, the editors of $P C$ quoted a shorter fragment: PC, vol. 28, p. 194. 
to 448). One of them was published in full, another was a postscript to a report, and yet another one was a one-sentence fragment from yet another letter. Thus, from the chronological perspective, from Solms's report dated 22 February/4 March 1768, the postscript only was published, in which the Prussian envoy wrote about Panin's forthcoming marriage to the well-dowried daughter of Chamberlain Petr Sheremetev, which he considered as strengthening the first minister's position. ${ }^{67}$ Nota bene, the editors did not mark that the printed text was just an addition to the despatch, and not the main document. In the latter Solms described Panin's reaction to information from Frederick II about the initiation by Austria and Spain, both hostile to the 'Northern System' and belonging to the alliance of the so-called southern states, of negotiations for the renewal of their defensive alliance of $1725 .{ }^{68}$ In Panin's view, the best remedy for the strengthening of the southern states was the further strengthening of the 'Northern System', which is a significant statement if we consider that the Prussians soon after took efforts to renew alliance with Russia. Besides, Panin shared with Solms his thoughts about France's conspiring against Russia. ${ }^{69}$ From the spring of 1768 the only report from Solms to be published in full was the one dated 18/29 March, containing Russian reaction to the outbreak of the Bar Confederacy. ${ }^{70}$ The text is significant, but it does not contain an important thread which is present in other reports from that period, namely, there is no information about Panin's opinion on the reasons for the outbreak of the confederacy, for

${ }^{67}$ Solms to Frederick II, 22 February/4 March 1768, SIRIO, vol. 37, pp. 139-40.

${ }^{68}$ On this subject see Frederick II to Solms, 31 January 1768, PC, vol. 27, pp. 29-30.

69 'Ce ministre [Panin - D.D.] est informé des cabales qu'on a tenté à la Porte pour l'engager de prendre part aux affaires de Pologne, et même que la cour de France y a fait proposer formellement d'entrer dans une alliance pour s'opposer, suivant l'expression Françoise, à l'énorme puissance de la Russie, mais les dernières nouvelles de Constantinople rassurent contre les suites de cette démarche', Solms to Ferderick II, 22 February/4 March 1768, GStAPK, 1. HA, Rep. 96, 57A, no. 424.

${ }^{70}$ SIRIO, vol. 37, pp. 141-47. The text in SIRIO contains certain stylistic differences as compared with the text in GStAPK, 1. HA, Rep. 96, 57A, no. 428, but there are also several other changes and omissions, for instance when Solms reported the possible scenarios of conduct outlined by Panin he wrote: 'on pourrait former, au plus tôt sous le nom du roi, une confédération', whereas in the original version it is 'une reconfédération'; when it is mentioned that the leaders of the Russian army will get 'les ordres les plus précis de respecter le territoire turc', the original version is more precise: 'de respecter les frontièrs de la Turquie'. The editors also omitted a few final sentences in the printed text without marking it. Those sentences contain information that the Saxon envoy in St Petersburg would return to Saxony, but it was not known what way he would take. Solms tried to convince Frederick II to consent for a route with a stop at the Prussian court. The diplomat thought that it would be easy to persuade his Saxon colleague to go via Berlin, if Frederick II agreed to promise him a personal audience in Potsdam. 
which he blamed France. ${ }^{71}$ Thus, this aspect of the Russian attitude toward the Confederacy of Bar does not exist for the reader of the Sbornik. Finally, from the third report of that period mentioned in SIRIO, only one sentence was published, which contained information on the death of Panin's fiancée 'Mademoiselle de Czeremetow' (nota bene in the original version the surname is less distorted - 'Scheremetoff') and his drowning in grief. In fact the three-page-long, partly encoded despatch contains much more information than this. ${ }^{72}$ The readers may, therefore, have the impression that Russo-Prussian relations in the spring of 1768 were dominated by the subject of the planned wedding of the Russian first minister (which was totally insignificant for Russo-Prussian relations in that period), besides which only the outbreak of the Bar Confederacy was noticed; Russia immediately had a ready method of overcoming it. But there was no information that the effective head of Russian foreign policy perceived France as the main threat for the interests of Catherine II's state, and that Russia evidently hesitated about the Confederacy of Bar.

A similar situation presents itself in the case of General Gottlob Curt von Tottleben who returned from exile to perform service for Russia; this was exposed in SIRIO. Restored to the favours of Catherine II, in 1769 he led the Russian expedition to Georgia. Extracted fragments of letters regarding Tottleben's return from Silesia and his arrest by the Prussians for debts create the impression of an important subject in Russo-Prussian relations, whereas in fact Tottleben's affair was a marginal matter. ${ }^{73}$ The illustration of this distortion are five sentences about Tottleben published in SIRIO, vol. 37 , as the only fragment of a long letter from Solms, dealing predominantly

${ }^{71}$ In another unprinted report Solms placed Panin's opinion that 'cette émeute [Bar Confederacy - D.D.], qui par les raisons susdites pourrait être d'autant plutôt étouffe, n'était que l'ouvrage de la France, qui ne cherchait en cela qu'à donner de l'occupation et à causer des embarras, et qui ayant réussi à occasionner des troubles, se mettait peu en peine des suites que ses intrigues pourraient avoir, formant peut être dans ce moment-ci déjà un autre projet, par laquelle elle croira pouvoir faire de la peine à la Russie et contrecarrer ses vues', Solms to Frederick II, 13/24 May 1768, GStAPK, 1. HA, Rep. 96, 57A, no. 440.

${ }^{72}$ For example about the slowdown of all state matters in connection with Panin's personal troubles and the departure of Catherine II and her son from St Petersburg in fear of smallpox. There are also interesting observations by Solms (sent in an encoded form) about the ambiguous attitude of Russian government towards the Bar Confederacy: 'Je ne saurais m'imaginer cependant, qu'on ignore ici la situation véritable des premières [confederates in Poland - D.D.]. Il me semble au contraire, qu'on veuille, ou s'étourdir là-dessus, et ne pas les regarder de conséquence, puisqu'on espère pouvoir les terminer, ou qu'on veut cacher au public l'impression qu'elles font', Solms to Frederick II, 20/30 May 1768, GStAPK, 1.HA, Rep. 96, 57A, no. 441.

${ }^{73}$ See SIRIO, vol. 37, pp. 218-30. 
with the Swedish crisis, the Turkish war and Russia's financial problems. I believe the letter was 'scissored' to conceal the troubles encountered by Russia at the beginning of the war with the Ottoman Empire. ${ }^{74}$ Zofia Zielińska was the first historian to mention that the Sbornik is an edition 'full of errors'. ${ }^{75}$ The explanation of such a large number of

${ }^{74}$ Solms to Frederick II, 24 March/ 4 April 1769, GStAPK, 1. HA, Rep. 96, no. 57B, no. 516; cf. SIRIO, vol.37, p. 223; similarly, letters omitted from SIRIO dealing with the important subject of the delivery to Russia of Prussian subsidies for the war with Turkey, and about problems with determining the rate of exchange of coinage and the place of cash transfers are: Solms to Frederick II, 4/15, 8/19 and 15/26 December 1769, GStAPK, 1. HA, Rep. 96, 57C, no. 582, 583, 584; and Solms to Frederick II, 12/23 January and 12/23 February 1770, GStAPK, 1. HA, Rep.96,57D, no. 591, 596; fragments with information about the disbursement of subsidies were omitted from Solms's report to Frederick II: 19/30 March 1770, GStAPK, 1. HA, Rep. 96, 57D, no. 604; cf. SIRIO, vol. 37, p. 276. Cf. note 51 above.

${ }^{75}$ As examples of errors distorting the sense of the source, one can mention the change of the name Ogiński to Czartoryski in the ministerial decoded version of Solms's report of 31 January 1764 (SIRIO, vol. 22, pp. 200-01) corrected by Zielińska based on the royal decoded version; similarly the name Rzewuski was corrected to Mniszech (SIRIO, vol. 22, p. 557), or the similar correction of place name 'Thorn' to 'Danzig' in Solms's report of 16 November 1764 (SIRIO, vol. 22, pp. 335-36), for these and other corrections, see Zielińska, Polska, p. 38, note 84, p. 84, note 19 (here the case of wrong name), p. 201, note 24, pp. 224-25, notes $120-22$, p. 251, note 224 (here the case of wrong place name), p. 287 , note 125 , p. 297 , note 169 , p. 301 , note 184 , p. 308 , note 211 , p. 312 , note 231 , p. 578 , note 121 (here the correction of the name), p. 658 , note 251. I can add a further example of an error from my own reading of the sources: in the report, in which Solms mentions for the first time the outbreak of the Bar Confederacy, in the printed version there is ' $\mathrm{j}$ 'ai l'honneur de lui mander que comme on s'attendait ici qu'après la cérémonie de la clôture de la diète à Varsovie, on pourrait jouir du fruit de son ouvrage, on avait déjà envoyé l'ordre aux troupes de retourner dans le pays selon les quartiers qui sont assignées aux différentes divisions' (SIRIO, vol. 37, p. 141). So the reader may have the impression that after the closure of the Sejm in Warsaw, the Russian army was ordered to withdraw to the places where it was stationed in the territory of Poland, whereas the original report leaves no doubt that troops got the order to withdraw to Russia: 'j'ai l'honneur de lui mander que comme on ne s'attendait qu'après la cérémonie de la clôture de la diète à Varsovie, que de jouir de fruit de son ouvrage, on avait déjà envoyé l'ordre aux troupes de retourner en Russie, aux quartiers fixes de leur divisions', Solms to Frederick II, 18/29 March 1768, GStAPK, 1.HA, Rep. 96, 57A, no. 428. Another example is the information in the report about the sending of the Russian ambassador in Warsaw for leave and replacing him with General Ivan Weymarn, Solms supposedly wrote that Catherine II 'l'approuvait [...] de lui [Weymarn - D.D.] donner le caractere représentatif' (SIRIO, vol. 37, p. 286), whereas in fact the text says that Catherine II gave consent 'sans lui donner un caractère représentatif', Solms to Frederick II, 27 April/8 May 1770, GStAPK, 1. HA, Rep. 96, 57D, no. 614. Similarly, when Solms wrote about 'la réponse personnelle de l'Impératrice de Russie envoyée au moins de Décembre dernier à Vienne moyennant une lettre particuliere au prince Galliczin, afin de prévenir la cour de Vienne sur le démembrement de la Pologne résolu entre V.M. et la Russie.' (SIRIO, vol. 37, p. 645), in the original there is 'pour préparer la cour de Vienne sur le démembrement': Solms to Frederick II, 3/14 February 1772, GStAPK, 1. HA, Rep. 96, 57J, no. 771. 
errors and differences (sometimes essential and sometimes stylistic) in the edition as against the original in the archive is - besides, as it seems, the carelessness of the editor - the source basis accessed by Herrmann (to which he was admitted), as discovered by Zielińska. ${ }^{76}$ Herrmann, who made extracts in Berlin, used the first decoded documents for ministry (preserved in Repository XI), which were less precise, often made in a hurry and containing errors, ${ }^{77}$ instead of the ones prepared for King Frederick II, which are kept in the set Geheimes Kabinett (Repository 96). The documents deciphered for the king were made on the copies of reports made especially for Frederick II after checking and correcting errors in extracts made for the needs of cabinet ministers. This explains differences in extracts and errors in the published texts, which can be noticed by any scholar who approaches the original sources. But here a question should be asked, which I cannot currently answer: did Herrmann know about the existence of another, royal, better decoded version? Even if he did not, he must have used the help of archivists, who must have known about it. So why did he choose (or why did other persons choose for him) the ministerial decoded version, which is less clear and full of errors?

As a marginal note to these considerations I would like to add that besides Prussian diplomatic materials I heve also had an opportunity to compare with the original sources the edition of the diplomatic correspondence of Austrian representatives residing in St Petersburg. This collection was published in four instalments (SIRIO, volumes 18, 46, 109, $125)$ covering the years 1762-76. The editor of the first 'Austrian' volume of the Sbornik was the aforementioned Schtendman. The remaining volumes were published under direction of the long-term chairman of the RIO and political patron of Schtendman, Aleksandr A. Polovtsov. The death of the latter stopped the edition of the 'Austrian' series. To my surprise, the extracts obtained by the RIO from the collections of the Vienna Haus- Hof- und Staatsarchiv proved to be of much better quality than those from Berlin. ${ }^{78}$ In volumes 109 and 125 of SIRIO, which I compared with the original sources, materials from Vienna archives were

${ }^{76}$ In her work on the Polish Commonwealth in the years 1763-66, Zielińska corrected the texts used in SIRIO, vol. 22, by studying the originals from GStAPK, Rep. 96. My research observations confirm in their entirety the need of such verification.

${ }^{77}$ The information that Herrmann used this repository with respect to ministerial correspondence is in the introduction to the second volume of Prussian materials: SIRIO, vol. 37, p. I, and in the footnote, SIRIO, vol. 37, p. 132.

${ }^{78}$ The originals of Lobkowitz's reports from 1767-75 are kept in the Haus-, Hofund Staatsarchiv (Vienna), Staatskanzelei 1500-1860 (hereafter HHStA), Rep. Rußland II, Berichte, no. 47-53. 
published in German, without Russian translations (translation was replaced by Russian summaries in the table of contents), and letter headings are also written in German, as if Russian editors did not interfere with the delivered extracts and limited themselves to giving the editorial numbers. These numbers - similarly to those in the 'Prussian' volumes - are not correlated with the original report numbers. These are marked in the edition which fragments were encoded, but the majority of attachments and certainly unencrypted poscripts are omitted. For the years 1767-75 covered by my queries, the edition of diplomatic reports of the Austrian envoy Joseph Lobkowitz is nearly complete. Only a part of the numbered reports, which did not contain encoded fragments, was omitted, ${ }^{79}$ as well as hand-written letters, not numbered, whose purpose was often clearly courtesy. ${ }^{80} \mathrm{Few}$ omissions in the text also relate only to unencoded fragments. The envoy was obliged to deliver a report every seven days and he diligently fulfilled this duty. Sometimes, due to his relatively low position at the Russian court and poor access to information, he had nothing to write about. But even then he informed the headquarters that he had no news, or he presented some minor details of social life. In such case the despatch was sent without encoding, and editors often omitted those fragments. In my opinion this is the main reason for the omissions in this edition. As far as significant omissions are concerned, one should mention the so-called general reports for a given year, sent as attachments to regular despatches. ${ }^{81}$ On the other hand, the decoded fragments of reports were published in full (this constitutes the majority of them, since Lobkowitz encoded all important information) with few errors of transcription, ${ }^{82}$ and those that were not encoded were sometimes replaced

${ }^{79}$ An example of such omission is in SIRIO, vol. 109 (1901), report no. 17 of 29 April 1768, with the information that there are no news from Poland, and that the Lithuanian Grand Master of the Kitchens, Michał Wielhorski, is in Petersburg, HHStA, Rep. Rußland II, Berichte, no. 49, fols 47-47v.

${ }^{80}$ Here we also have exceptions, such as the publication of an unnumbered letter from Lobkowitz to Wenzel von Kaunitz of 29 March 1771: SIRIO, vol. 109, pp. 516-17, but it was not marked in the edition that this was not a regular report.

${ }^{81}$ The editors of SIRIO, vol. 109, omitted the first of such reports sent as an attachment to report of 30 August 1770, 'Rapport général du Prince Joseph de Lobkowitz, ministre plenip. de Leurs Majestés Impériales à la cour de Russie, pour l'année 1769', HHStA, Rep. Rußland II, Berichte, no. 49: Relationen 1768-1770, fols 248-51. It contains information on the financial crisis in Russia and the condition of Russian army.

${ }^{82}$ Besides individual errors of transcription there are also other mistakes; a misread date (for example 18 instead of 19 April 1771, SIRIO, vol. 109, p. 522; 12 instead of 4 February 1772, SIRIO, vol. 125, St Petersburg, 1906, p. 12); other defects include publishing the post scriptum to the report of 9 May 1769 as a separate report (with the same date), SIRIO, vol. 109, pp. 272-73. 
with abstracts. But these are not abstracts made by the editors of SIRIO. The eighteenth-century summaries of particular fragments of reports made by the Vienna chancellery and placed on the other side of the originals of letters were used. Sometimes only summaries of letters were published and marked with the word 'extract'. ' $^{83}$

In the context of this correspondence it should be noted that Vienna was not the main political partner of Catherine II at the beginning of her reign. Until 1772 both states were on opposite sides of the European political scene, and in the initial phase of the Russian-Turkish war, Prussian mediation was of key importance for their mutual relations (1768-74). Moreover, important matters that St Petersburg and Vienna had to communicate directly to each other did not go through Lobkowitz, the prestige of whose mission Russia tried to diminish. A much more important channel of communication was the Russian envoy in Vienna, Dimitrii M. Golicyn. This is why the correspondence of Lobkowitz, who was not admitted in St Petersburg to participate in discussions about problems important for Russia, does not contain information which SIRIO editors could consider strategically significant for the picture of Russian politics at that time. Maybe this is the reason why this correspondence was published in such a carefully elaborated form as compared with the Prussian one, and without interference of censorship.

Summing up the above considerations I can state on the basis of my experience of work with Prussian materials that I have no doubt that SIRIO contains only small fragments of the reports of the Prussian envoy in St Petersburg, Solms, who wrote about everything that happened at the Russian court and was a good observer whose reports are valuable for researchers. What was published is often fragments of reports. In my opinion the selection of these fragments in many cases resulted from the realization of specific goals which this edition was supposed to meet. But I have often had the impression of chaos, especially when several consecutive reports were omitted in the edition, and they contained information on the threads which had earlier appeared in the Sbornik.

It is also clear that in the 'Prussian' volumes of SIRIO, the most highlighted moments, besides the conclusion of the Russo-Prussian alliance and the conduct of the Polish election, concerned the partition negotiations. All these points can be considered the climactic moments of Russian foreign policy in the first years of Catherine II's reign. But the editors omitted key events of this period, such as the first years of Russo-Turkish war

${ }^{83}$ Examples of such summaries which replaced the whole reports: Lobkowitz to Kaunitz, 23 February, 2 March, 15 April 1767, SIRIO, vol. 109, pp. 227, 228, 236. 
(1768-74), the period of crisis for the Russian domination in Sweden in 1769 and the initial period of the Bar Confederacy (from 1768), when the 'Northern System', which was a basis of Russian domination, encountered difficulties. St Petersburg was then under strong pressure from Berlin and Vienna, both of which wanted the swift end of the war and the limitation of Russian domination in eastern and south-eastern Europe. It was also the period when binding decisions regarding the fate of Poland were taken at the Russian court. Solms was the witness, participant and chronicler of these events. His reports from the period 1768-71 belong to the most important source evidence providing the picture of St Petersburg's policies. Yet most of these reports are not published in SIRIO. The year 1772 , from which most of his reports were published, is a completely different situation. By this time Russia was again a power dominating in eastern and southern Europe politics, and had tipped the balance of victory in the war with the Ottoman Empire in its favour. 1773 saw, on the one hand, the forcing of the Polish Commonwealth to recognize the partition, and on the other, the beginning of Russia's problems, as it was forced to oppose the excessive appetite for annexations of its German allies regarding territories of the Polish Commonwealth much greater than those stipulated in the 1772 Treaty of St Petersburg. Besides, this was a moment, when a reshuffle began at the Russian court in connection with recognition by Catherine II of the age of majority of the Grand Duke Paul and his marriage with Wilhelmina Luiza von Hessen-Darmstadt. Here again, the editors of SIRIO omitted much information on this subject.

I also wish to quote the opinion of Ol'ga Kamardina, who stated that 'all [...] shortcomings in the activity of the RIO and in its scientific production require a critical approach of the readers using RIO publications to the texts of documents and their back matter'. Signalling the need of caution related to RIO publications did not stop this historian from commenting that "provided they take a critical approach, scholars may use and do use RIO publications because they contain many important and reliable pieces of information needed for studies on numerous issues in Russia's history, especially in the eighteenth century' ${ }^{84}$ This judgement, similarly to the over-optimistic opinion of Hamish M. Scott mentioned above, cannot be shared in the light of my analysis of the Prussian materials. Researchers

84 ‘Все [...] недостатки в деятельности РИО, в его научной продукции требуют от исследователей, пользующихся публикациями Общества, критического подхода к оценке текста документов и справочного аппарата к ним. [...] При критическом подходе публикации РИО могут быть использованы и используются учеными, ибо они содержат много важных и достоверных сведений для изучения ряда вопросов истории России преимущественно XVIII века', Kamardina, 'Imperatorskoe Russkoe'. 
who want to use the Prussian diplomatic correspondence published by the RIO have to confront the records in SIRIO with the documents in the Berlin GStAPK. If they resign from this effort, they are left with an edition which does not meet the criteria of scholarly publication. It is prepared messily, and - first and foremost - it is an edition with a thesis that distorts historical reality. On the other hand, the caution and critical approach to Austrian diplomatic correspondence recommended by Kamardina is - in my opinion - a sufficient tool which allows us to use these volumes of the Sbornik. This shows that SIRIO is a complex publication, not easy to assess as a whole. Knowledge of who prepared materials for publication, and how, should be an essential element of external source criticism, if we conduct research of the source material accessible in print only through the Sbornik.

(Translated by Elżbieta Petrajtis-O’Neill)

\section{Summary}

Between 1867 and 1918 the Imperial Russian Historical Society acting under the patronage of the Ministry of Foreign Affairs of the Russian Empire published in 148 volumes the Sbornik Imperatorskogo Russkogo Istoricheskogo Obshchestva (SIRIO). It contains, without limitation, Prussian diplomatic reports sent from Russia in the period 1763-74 by the envoy Victor Solms (volumes 22, 37 and 72). Researchers using SIRIO have different opinions on this edition. To verify the quality of this edition I compared it with the original sources, that is the reports by Solms for the period 1768-73 from the collections of the Geheimes Staatsarchiv Preußischer Kulturbesitz in Berlin-Dahlem. For the period 1763-67 I used Zofia Zielińska's findings. Drawing on archival resources revealed that only about 40.5 per cent of the reports were published in SIRIO, and most texts were - without informing the reader - subject to more or less significant intervention, which often totally distorted the message contained in them. Moreover, the edition contains many errors resulting from choosing as a basis the first, working, cabinet decoded version, instead of the final one prepared for Frederick II. Unequal stress put on reports from particular years and the selection of particular fragments of texts for publication results from the fact that publishing Prussian diplomatic materials in SIRIO was supposed to hide the crisis of Russian foreign policy at the beginning of the war with the Ottoman Empire (1768-74) and to emphasize the role of Prussia in the first partition of Poland. Comparing the Austrian diplomatic reports placed in the same publication (volumes 18, 46, 109 and 125) with the original sources for the years 1767-75 did not reveal similar shortcomings.

(Translated by Elżbieta Petrajtis-O’Neill) 


\section{Bibliography/Literature}

Agapova, Mariia Iu. [Агапова, Мария Ю.], 'Sborniki Russkogo istoricheskogo obshchestva kak istoricheskii istochnik [Сборники Русского исторического общества как исторический источник]', Russkii istoricheskii sbornik [Русский исторический сборник], 2, (Moscow) 2010, pp. 402-11.

Belousova, Ol'ga V. [Белоусова, Ольга В.], 'Opisanie zasedanii Russkogo istoricheskogo obshchestva v dnevnikakh grafa S.D. Sheremeteva [Описание заседаний Русского исторического общества в дневниках графа С.Д. Шереметева]', in Gatchinskii dvorets v istorii Rossii: Konferentsiia 1-3 dekabria 2016 goda priurochena k150-letiiu Rossiiskogo istoricheskogo obshchestva i 250-letiiu Gatchinskogo dvortsa [Гатчинский дворец в истории России: Конференция 1-3 декабря 2016 года приурочена к 150-летию Российского исторического общества и 250-летию Гатчинского дворија], ed. Svetlana A. Astahovskaia and Elena V. Minkina, St Petersburg: GMZ 'Gatchina', 2016, pp.38-48.

Błachowska, Katarzyna, 'Państwo, które ostać się nie mogło - spojrzenie historiografii rosyjskiej drugiej połowy XIX w. na dzieje Polski', in W cieniu wojen i rozbiorów: Studia z dziejów Rzeczypospolitej XVIII i początków XIX wieku, ed. Urszula Kosińska, Dorota Dukwicz and Adam Danilczyk, Warsaw: Neriton, 2014, pp. 499-522.

Dukwicz, Dorota, Rosja wobec sejmu rozbiorowego warszawskiego (1772-1775), Warsaw: Instytut Historii PAN, 2015.

'Istoriia Rossiiskogo istoricheskogo obshchestva [История Российского исторического общества]' 〈https://historyrussia.org/ob-obshchestve/istoriya. html $>$ [accessed 29 March 2019].

Kamardina, Ol'ga V. [Камардина, Ольга B.], 'Imperatorskoe Russkoe istoricheskoe obshchestvo: ocherk istorii i nauchnoi deiatel'nosti: 1866-1916 gg. [Императорское Русское историческое общество: очерк истории и научной деятельности: 1866-1916 гг.]', unpublished dissertation, Samara, 1999, 〈http://cheloveknauka.com/imperatorskoe-russkoe-istoricheskoe -obschestvo $\rangle$ [accessed 11 April 2019].

Kaplan, Herbert H., The First Partition of Poland, New York and London: Columbia University Press, 1962.

Kaplan, Vera, Historian and Historical Societies in the Public Life of Imperial Russia, Bloomington, IN: University of Indiana Press, 2017.

Konopczyński, Władysław, Konfederacja barska, 2nd edition, 2 vols, Warsaw: Volumen, 1991.

Lukowski, George T., The Szlachta and the Confederacy of Radom, 1764-1767/68: A Study of the Polish Nobility, Rome: Institutum Historicum Polonicum Roma, 1977.

Madariaga, Isabel de, Russia in the Age of Catherine the Great, London: Phoenix, 2002. 
Politische Correspondenz Friedrich's des Großen, vols 28-31, ed. Gustav B. Volz, Berlin: Verlag von Alexander Duncker, 1903-06.

Ransel, David L., The Politics of Catherinian Russia: The Panin Party, New Haven, CT: Yale University Press, 1975.

Scott, H.M., The Emergence of the Eastern Powers, 1756-1775, Cambridge: Cambridge University Press, 2001.

Sbornik Imperatorskogo Russkogo Istoricheskogo Obshchestva [Сборник Императорского Русского Исторического Общества], vols 12, 20, 22, 37, 72, 109, 125, St Petersburg, 1873-1906.

Sorel, Albert, La Question d'Orient au XVIII siècle: le partage de la Pologne et le traité de Kaïnardji, 1st edn, Paris: Plon, 1877, 2nd edn, Paris: Plon, 1889.

Stengel, Edmund, 'Herrmann Ernst Adolf H.', in Allgemeine Deutsche Biographie, vol.55, 1910, pp. 489-93, 〈https://www.deutsche-biographie.de/pnd124361080.html〉 [accessed 23 April 2019].

Stribrny, Wolfgang, Die Russlandpolitik Friedrichs des Grossen 1764-1786, Würzburg: Holzner Verlag, 1966.

Zielińska, Zofia, Polska w okowach ‘Systemu Północnego’ 1763-1766, Cracow: Arcana, 2012.

Zielińska, Zofia, Studia z dziejów stosunków polsko-rosyjskich w XVIII wieku, Warsaw: Semper, 2001.

Manuscripts:

Prussian diplomatic correspondence from the period 1768-73, Geheimen Staatsarchiv Preußischer Kulturbesitz (Berlin-Dahlem), Hauptabteilung 1., Repositur 96: Geheimes Kabinett, ältere Periode, 57 A-L, 58 A-C.

Austrian diplomatic correspondence from the period 1767-75, Haus-, Hof- und Staatsarchiv, Staatskanzelei 1500-1860, Rep. Rußland II, Berichte, 47-53.

Biography: Dr Dorota Dukwicz - assistant professor at the Tadeusz Manteuffel Institute of History of the Polish Academy of Sciences; researches the political history of the eighteenth century, with particular attention to the Polish-Lithuanian Commonwealth and its relations with Russia and Prussia; contact: ddukwicz@ihpan.edu.pl. 